\title{
Influence of section depth on the structural behaviour of reinforced concrete continuous deep beams
}

\author{
K.-H. Yang*, H.-S. Chung† and A. F. Ashourt \\ Mokpo University; Chungang University; University of Bradford
}

\begin{abstract}
Although the depth of reinforced concrete deep beams is much higher than that of slender beams, extensive existing tests on deep beams have focused on simply supported beams with a scaled depth below $600 \mathrm{~mm}$. In the present paper, test results of 12 two-span reinforced concrete deep beams are reported. The main parameters investigated were the beam depth, which is varied from $400 \mathrm{~mm}$ to $720 \mathrm{~mm}$, concrete compressive strength and shear span-tooverall depth ratio. All beams had the same longitudinal top and bottom reinforcement and no web reinforcement to assess the effect of changing the beam depth on the shear strength of such beams. All beams tested failed owing to a significant diagonal crack connecting the edges of the load and intermediate support plates. The influence of beam depth on shear strength was more pronounced on continuous deep beams than simple ones and on beams having higher concrete compressive strength. A numerical technique based on the upper bound analysis of the plasticity theory was developed to assess the load capacity of continuous deep beams. The influence of the beam depth was covered by the effectiveness factor of concrete in compression to cater for size effect. Comparisons between the total capacity from the proposed technique and that experimentally measured in the current investigation and elsewhere show good agreement, even though the section depth of beams is varied.
\end{abstract}

\section{Notation}

$A_{\text {st }}$ area of longitudinal bottom reinforcement

$A_{\text {st }}^{\prime} \quad$ area of longitudinal top reinforcement

$a \quad$ shear span distance measured from centre of support to centre of loading point

$b_{\mathrm{w}} \quad$ width of beam

$d$ effective depth of beam

$d_{\mathrm{a}} \quad$ maximum size of aggregate

$E_{\mathrm{s}} \quad$ elastic modulus of reinforcement

$f_{\mathrm{c}}^{\prime} \quad$ cylinder compressive strength of concrete

$f_{\mathrm{c}}^{*} \quad$ effective strength of concrete

$f_{\text {su }}$ tensile strength of reinforcement

$f_{\mathrm{y}} \quad$ yield strength of reinforcement

$h$ overall depth of beam

* Department of Architectural Engineering, Mokpo National University, Jeonnam, South Korea

$\dagger$ Department of Architectural Engineering, Chungang University, Seoul, South Korea

$\ddagger$ School of Engineering, Design and Technology, University of Bradford, UK.

(MCR 61541) Paper received 17 May 2006; last revised 20 September 2006; accepted 13 April 2007 $l_{\mathrm{p}} \quad$ width of loading plate

$P_{\text {cr }} \quad$ initial diagonal cracking load

$P_{\mathrm{fl}} \quad$ initial flexural cracking load

$P_{\mathrm{n}} \quad$ ultimate load capacity

$r$ distance between the midpoint of the chord of the yield line and the instantaneous centre

$V_{\text {cr }} \quad$ initial diagonal cracking shear strength

$V_{\mathrm{fl}} \quad$ initial flexural cracking shear strength

$V_{\mathrm{n}} \quad$ ultimate shear strength

$v_{\mathrm{e}} \quad$ effective strength factor

$W_{\mathrm{c}}$ internal energy dissipated in concrete

$W_{\mathrm{E}}$ external work done by applied load

$W_{\mathrm{I}}$ total internal energy dissipated in yield line

$W_{\mathrm{s}}$ internal energy dissipated in reinforcement

$\alpha \quad$ angle between the relative displacement at the midpoints of the chord and yield line

$\beta \quad$ angle between yield line and longitudinal axis.

$\delta \quad$ relative displacement vector across a yield line

$\varepsilon_{\mathrm{y}} \quad$ yield strain of reinforcement

$\xi \quad$ size effect factor

$\rho_{\mathrm{s}} \quad$ longitudinal bottom reinforcement ratio $\left(=A_{\mathrm{st}} / b_{\mathrm{w}} d\right)$

$\rho_{\mathrm{s}}^{\prime} \quad$ longitudinal top reinforcement ratio $\left(=A_{\mathrm{st}}^{\prime} / b_{\mathrm{w}} d\right)$

$\omega$ rotational displacement of rigid block I 


\section{Introduction}

Reinforced concrete deep beams, which frequently occur in practice as transfer girders, pile caps and foundation walls, are commonly supported over several supports. However, most of the existing investigations to study the structural behaviour and strength of deep beams have focused on single-span deep beams and very little published data ${ }^{1-4}$ exist on continuous deep beams. As a result, their main design codes based on test results of simply supported deep beams or on continuous shallow beams, such as ACI $318-99^{5}$ and CIRIA Guide $2,{ }^{6}$ have been found to be inadequate in the case of continuous deep beams. ${ }^{1-3}$

Failure mechanisms for continuous deep beams are significantly different from those for simply supported deep beams. The conventional elastic beam theory, which is applicable to slender beams, is not able to predict the behaviour of continuous deep beams owing to high shear deformation and non-linear strain distribution across the deep beam section. The region of high moment and high shear in continuous deep beams coincides and failure usually occurs in this region, whereas in simply supported deep beams, high shear and high moment occur at different locations. The coexistence of high shear and high moment in continuous deep beams as pointed out by Rogowsky et al. ${ }^{3}$ and the development of tensile strains in longitudinal top and bottom reinforcement could cause a significant reduction in the effective strength of concrete struts, which are the main load transfer element in deep beams.

It is well known that size effect occurs in concrete beams without shear reinforcement failing in shear; that is, shear strength decreases as the size of beam increases. ${ }^{7-11}$ However, several hypotheses were developed to explain the effect of size on shear strength of concrete beams. Taylor ${ }^{10}$ showed that aggregate interlock across shear cracks substantially contributes to the shear strength. As a result, increasing the beam size, while keeping the aggregate size constant, should inevitably cause a decrease of the aggregate interlock contribution and, consequently, a decrease in shear strength. On the other hand, Bažant et al. ${ }^{7,8}$ and Walraven and Lehwalter ${ }^{11}$ proposed that fracture mechanics would describe the size effect in concrete structure failing owing to diagonal shear. Based on non-linear fracture mechanics theory, Bažant and $\mathrm{Kim}^{8}$ developed a size effect formula to consider the decrease in shear strength as the beam depth increases; this formula is adopted to modify the concrete properties used in the mechanism analysis presented in the current paper. Test results of simple deep beams performed by Tan and $\mathrm{Lu}^{12}$ and Yang et al. ${ }^{13}$ showed that with the increase of section depth, the ultimate strength significantly decreased and the ACI 318-99 predictions became unconservative.

In the present paper, test results of 12 two-span reinforced concrete deep beams are reported. The influence of section depth on the ultimate shear strength according to the variation of concrete strength and shear span-to-overall depth ratio in continuous deep beams is compared with that in the corresponding simple ones. Also a numerical technique based on the upper-bound plasticity theory, considering size effect is proposed.

\section{Significance of research}

Most existing tests on deep beams have concentrated on simply supported beams having scaled section depth below $600 \mathrm{~mm}$. The test results reported in the current paper show that the influence of section depth on the structural behaviour and ultimate strength is more pronounced on continuous deep beams than simple ones and on beams having higher concrete compressive strength.

\section{Test specimens}

The details of geometrical dimensions and reinforcement for test specimens are shown in Table 1 and Fig. 1. Main variables investigated were beam depth, $h$, ranged from $400 \mathrm{~mm}$ to $720 \mathrm{~mm}$, compressive strength of concrete, $f_{\mathrm{c}}^{\prime}$, and shear span-to-overall depth ratio, $a / h$. The beams tested were classified into two groups according to the concrete compressive strength: Lseries for concrete design strength of $27 \mathrm{MPa}$ and $\mathrm{H}$ series for concrete design strength of $60 \mathrm{MPa}$. The shear span-to-overall depth ratios, $a / h$, were initially designed to be 0.5 and 1.0 to allow comparisons of current results with those reported by Yang et al. ${ }^{13}$ for simple deep beams. However, $a / h$ in H-series was increased from 0.5 to $0 \cdot 6$, as the load capacity of beams having $f_{\mathrm{c}}^{\prime}$ of $60 \mathrm{MPa}$ and $a / h$ ratios of 0.5 had exceeded the capacity of the loading machine in the pilot test. The beam notation given in Table 1 includes three parts. The first part refers to concrete strength: L for low concrete strength and $\mathrm{H}$ for high concrete strength. The second part is used to identify the shear span-to-overall depth ratio and the third part gives the section overall depth in $\mathrm{cm}$. For example, L5-60 is a continuous deep beam having a low concrete strength, shear span-to-overall depth ratio of 0.5 and overall depth of $600 \mathrm{~mm}$.

All tested beams had the same section width and longitudinal reinforcement ratio: the section width, $b_{\mathrm{w}}$, was $160 \mathrm{~mm}$ and longitudinal top and bottom reinforcement ratios were $1 \%$. The total length of test specimens varied according to the $a / h$ ratio as given in Table 1 . The distance between the soffit of beams and centre of longitudinal reinforcement was $45 \mathrm{~mm}$ for beams having section depths of $400 \mathrm{~mm}$ and $600 \mathrm{~mm}$, and $67 \mathrm{~mm}$ for beams with section depth of $720 \mathrm{~mm}$. The longitudinal bottom reinforcement was continuous over the 
Table 1. Details of test specimens

\begin{tabular}{|c|c|c|c|c|c|c|c|c|}
\hline Specimen & $f_{\mathrm{c}}^{\prime}: \mathrm{MPa}$ & $a / h$ & $h: \mathrm{mm}$ & $a: \mathrm{mm}$ & $d: \mathrm{mm}$ & $L: \mathrm{mm}$ & $A_{\mathrm{st}}=A_{\mathrm{st}}^{\prime}: \mathrm{mm}^{2}$ & $\rho_{\mathrm{s}}=\rho_{\mathrm{s}}^{\prime}$ \\
\hline L5-40 & $32 \cdot 4$ & 0.5 & 400 & 200 & 355 & 400 & 574 & $0 \cdot 01$ \\
\hline L5-60 & & & 600 & 300 & 555 & 600 & 861 & 0.0097 \\
\hline L5-72 & & & 720 & 360 & 653 & 720 & 1148 & $0 \cdot 011$ \\
\hline L10-40 & $32 \cdot 1$ & 1.0 & 400 & 400 & 355 & 800 & 574 & $0 \cdot 01$ \\
\hline L10-60 & & & 600 & 600 & 555 & 1200 & 861 & 0.0097 \\
\hline L10-72 & & & 720 & 720 & 653 & 1440 & 1148 & $0 \cdot 011$ \\
\hline $\mathrm{H} 6-40$ & $65 \cdot 1$ & 0.6 & 400 & 240 & 355 & 480 & 574 & $0 \cdot 01$ \\
\hline H6-60 & & & 600 & 360 & 555 & 720 & 861 & 0.0097 \\
\hline H6-72 & & & 720 & 432 & 653 & 864 & 1148 & $0 \cdot 011$ \\
\hline $\mathrm{H} 10-40$ & $67 \cdot 5$ & 1.0 & 400 & 400 & 355 & 800 & 574 & $0 \cdot 01$ \\
\hline H10-60 & $68 \cdot 2$ & & 600 & 600 & 555 & 1200 & 861 & 0.0097 \\
\hline $\mathrm{H} 10-72$ & $67 \cdot 5$ & & 720 & 720 & 653 & 1440 & 1148 & $0 \cdot 011$ \\
\hline
\end{tabular}

Note: $f_{\mathrm{c}}^{\prime}=$ cylinder compressive strength, $a / h=$ shear span-to-overall depth ratio, $h=$ section overall depth, $a=$ shear span, $d=$ effective section depth, $L=$ beam span, $A_{\mathrm{st}}=$ total area of longitudinal bottom reinforcement, $A_{\mathrm{st}}^{\prime}=$ total area of longitudinal top reinforcement, $\rho_{\mathrm{s}}=$ longitudinal bottom reinforcement ratio $\left(=A_{\mathrm{st}} / b_{\mathrm{w}} d\right), \rho_{\mathrm{s}}^{\prime}=$ longitudinal top reinforcement ratio $\left(=A_{\mathrm{st}}^{\prime} / b_{\mathrm{w}} d\right)$ and $b_{\mathrm{w}}=$ beam width



Fig. 1. Details of beam geometry and arrangement of reinforcements

full length of the beam and welded to $160 \times$ $100 \times 10 \mathrm{~mm}$ end plates to provide sufficient anchorage. The longitudinal top reinforcement was anchored within the outside of exterior supports by $90^{\circ}$ hooks according to ACI $318-05^{14}$ as shown in Fig. 1. To examine the influence of the size effect on concrete continuous deep beams, no shear reinforcement was provided.

\section{Material properties}

Figure 2 shows the stress-strain relationship of the $19 \mathrm{~mm}$ diameter steel reinforcing bar used in test speci-

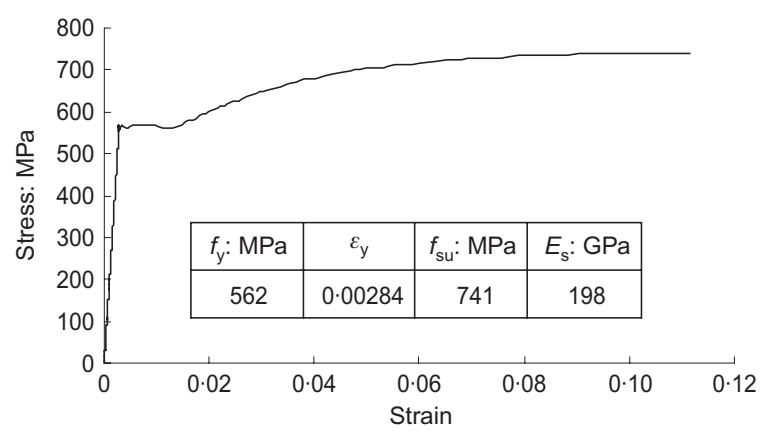

Fig. 2. Stress-strain curve of longitudinal reinforcement mens. The ingredients of ready-mixed concrete were ordinary Portland cement, fly ash, irregular gravel of a maximum size of $25 \mathrm{~mm}$ and sand. The water/binder ratios of L-series added with fly ash of $12 \%$ and of $\mathrm{H}-$ series added with fly ash of $20 \%$ were 0.41 and 0.27 , respectively. All specimens were cast in a vertical position in the same wooden mould. Control specimens of $100 \mathrm{~mm}$ diameter $\times 200 \mathrm{~mm}$ high cylinder were cast and cured simultaneously with beams in order to determine the compressive strength of concrete. The results of the compressive strength, $f_{\mathrm{c}}^{\prime}$, given in Table 1 are the average value of testing nine cylinders soon after each beam test.

\section{Test set-up}

Loading and support arrangements are shown in Fig. 3. All beams having two spans were tested to failure under two-point symmetrical top loads with loading rate of $3 \mathrm{kN} / \mathrm{min}$ using a $3000 \mathrm{kN}$ capacity universal testing machine. One beam span was identified by Espan and the other as W-span, as shown in Fig. 1. The two exterior end supports are designed to allow horizontal and rotational movements, whereas the intermediate support prevents horizontal movement but allows rotation. In order to evaluate the shear force and loading distribution, $1000 \mathrm{kN}$ capacity load cells were installed in both exterior supports. At the location of loading or support point, a steel plate of $100 \mathrm{~mm}$ or $200 \mathrm{~mm}$ wide was provided to prevent premature crushing or bearing failure as shown in Fig. 3. All beams were preloaded up to a total load of $150 \mathrm{kN}$ before testing, which would not produce any cracks, in order to assure a similar loading distribution to supports to the result of linear two-dimensional finite-element (2D FE) analysis.

Vertical deflections at a distance $0.45-0.47 L$ from the exterior support, which is the location of maximum deflection predicted by linear FE analysis, and at the 


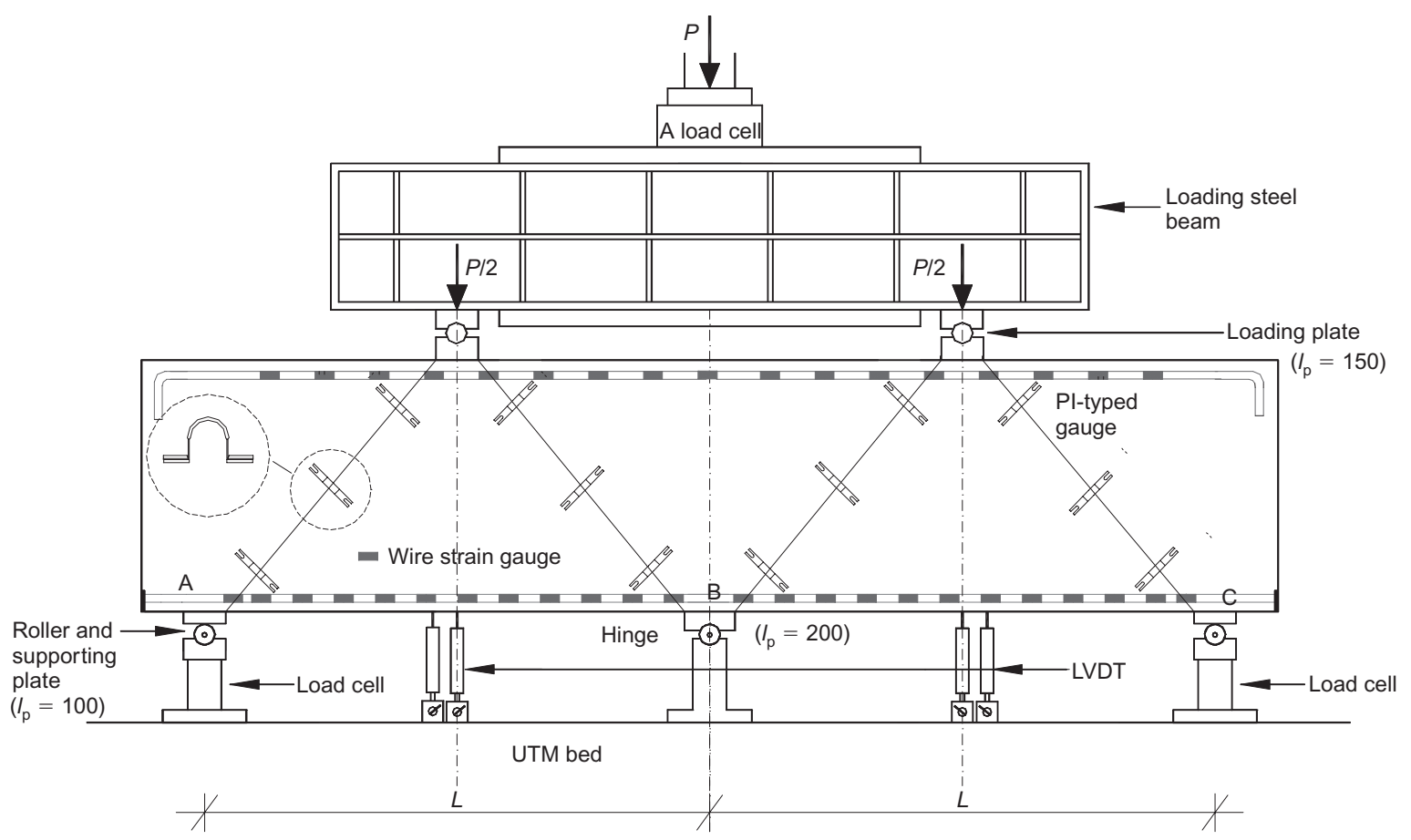

Fig. 3. Test set-up of specimen (dimensions in $\mathrm{mm}$ )

mid-span of each span as well as support settlements were measured using linear variable differential transducers (LVDTs). The beam surface was whitewashed to aid the observation of crack development during testing. After each load increment, the load was kept constant while cracks were marked and photographed. The inclined crack width of concrete struts joining the edges of load and support plates was monitored by the $\pi$-shaped displacement transducers (PI gauges) as shown in Fig. 3. The strains in longitudinal top and bottom reinforcement were measured by $5 \mathrm{~mm}$ electrical resistance strain gauges (ERSs) bonded at spacing of $50 \mathrm{~mm}$ and $100 \mathrm{~mm}$ along the bar length in beams having $a / h=0 \cdot 5$ and $a / h=1 \cdot 0$, respectively. At each load increment, the test data were captured by a data logger and automatically stored.

\section{Support settlements}

Continuous deep beams are sensitive to differential support settlements, causing additional moment and shear in structural members. To assess the effect of differential settlements on beams tested, a linear 2D FE analysis considering shear deformation effect was performed on beams shown in Fig. 1. For the beams tested, the sources of relative support settlements were the elastic shortening of the load cell and plates, and elastic deformation of the bed of the testing machine. The second moment of area of the testing machine bed cross-section about the bending axis is $3.2 \times 10^{10} \mathrm{~mm}^{4}$, ${ }^{4}$, then the elastic deformation under a point load $R$ (in
$\mathrm{kN}$ ) at a distance $1500 \mathrm{~mm}$ from the centre of testing machine is $0.000176 \mathrm{Rmm}$. The amount of elastic shortening owing to a load at the exterior and intermediate supports involving the load cell and plates was considered in designing the support size. When $a / h$ ratio is $0 \cdot 5$, the reactions of the exterior and intermediate supports owing to the total applied load $P$, from the linear $2 \mathrm{D} \mathrm{FE}$ analysis, are $0 \cdot 2 P$ and $0 \cdot 6 P$, respectively. As the height of the intermediate support is equal to that of the exterior load cell, the section area of the intermediate support was designed to be three times wider than that of the load cell at the exterior support to produce the same elastic shortening. Fig. 4 shows the result of support settlement recorded from a pilot test. The maximum settlement of the exterior support relative to the intermediate support was in order of $L /$ 25000 . For a differential settlement between the exter-

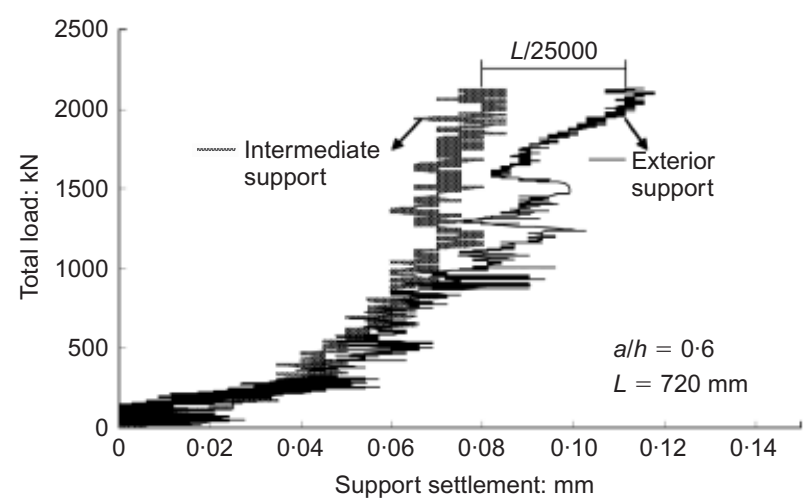

Fig. 4. Total load plotted against support settlement

Magazine of Concrete Research, 2007, 59, No. 8 
ior and intermediate supports of $\mathrm{L} / 25000$, the maximum additional shear force obtained from linear $2 \mathrm{D}$ FE analysis is $25 \mathrm{kN}$ and $7 \mathrm{kN}$ for beams having $a / h$ ratio of 0.5 and 1.0 , respectively. This indicates that the differential settlement had no significant effect on the test arrangement.

\section{Test results}

\section{Crack propagation and failure mode}

The total load and shear force at the development of the first flexural and shear cracks and crack pattern at failure in L-series are shown in Table 2 and Fig. 5, respectively. The failure modes and crack pattern in $\mathrm{H}-$ series were similar to those in L-series but lager failure zone. Just before failure, the two spans showed nearly the same crack patterns. The crack pattern development was significantly influenced by both $a / h$ ratio and section depth. For $a / h=0 \cdot 5$, the first diagonal crack developed suddenly at about $40 \%$ of the load capacity at the mid-depth of the concrete strut within the interior shear span, and then the first flexural crack in the sagging region immediately followed. The first flexural crack over the intermediate support generally occurred at about $80 \%$ of the ultimate load capacity, and its development height up to failure ranged between $0 \cdot 2 \mathrm{~h}$ and $0.4 \mathrm{~h}$. As the load increased, more flexural and diagonal cracks were formed and a diagonal crack extended to join the edges of the load and intermediate support plates. A diagonal crack within the exterior shear span suddenly occurred near to the failure load. For beams having $a / h=1 \cdot 0$, the first crack developed vertically in the hogging zone, followed by a diagonal crack in the interior shear span and then a vertical crack in the sagging zone. Diagonal cracks within the exterior shear span are seldom developed, exhibiting different crack patterns from that observed in beams with $a / h=0 \cdot 5$. The height and average spacing of the sagging and hogging flexural cracks up to failure were from $0 \cdot 6 h$ to $0 \cdot 8 h$ and $50 \mathrm{~mm}$, respectively.

With the increase of $h$, the number of cracks formed decreased and their depth was also reduced because of the increase of the energy release rate and expansion of crack width, which caused brittle failure, as described by Bažant and Planas ${ }^{7}$ and given by Fig. 6, which shows the development of diagonal crack width. The diagonal crack width of H6-72 and H10-72 beams are not presented in Fig. 6 as the PI gauges were damaged when diagonal cracks occurred. The width of diagonal cracks which occurred within the interior shear span extended up to $0 \cdot 6-1.5 \mathrm{~mm}$ at failure. The shear spanto-overall depth ratio had a significant influence on the development of diagonal crack width. As the load increased, widening of the diagonal crack greatly increased with the increase of shear span-to-overall depth ratio. All beams having $a / h=1.0$ failed soon after the development of the diagonal crack between the edges of the applied load and intermediate support plates. Whereas for beams having $a / h=0 \cdot 5$, the diagonal crack width increased with the increase of section overall depth. With the increase of diagonal crack width, the load transfer by frictional effect and aggregate interlock is reduced, showing the influence of the beam size as described by Reineck. ${ }^{15}$

All beams exhibited the same mode of failure as observed in other experiments. ${ }^{1}$ At failure, an end block formed because of the significant diagonal crack connecting the edges of the load and intermediate support plates and rotated about the exterior support, leav-

Table 2. Summary of test results

\begin{tabular}{|c|c|c|c|c|c|c|c|c|c|c|c|c|c|c|}
\hline \multirow[t]{4}{*}{ Specimen } & \multicolumn{3}{|c|}{$\begin{array}{l}\text { Initial flexural cracking load } \\
P_{\mathrm{fl}}: \mathrm{kN}\end{array}$} & \multicolumn{8}{|c|}{ Diagonal cracking load $\left(P_{\text {cr }}\right)$ and shear force $\left(V_{\text {cr }}\right): \mathrm{kN}$} & \multicolumn{3}{|c|}{$\begin{array}{l}\text { Failure load }\left(P_{\mathrm{n}}\right) \text { and } \\
\text { ultimate shear force }\left(V_{\mathrm{n}}\right): \mathrm{kN}\end{array}$} \\
\hline & \multirow{3}{*}{$\begin{array}{c}\text { Hogg- } \\
\text { ing } \\
\text { zone } \\
\left(P_{\mathrm{fl}}\right)_{\mathrm{N}}\end{array}$} & \multicolumn{2}{|c|}{$\begin{array}{l}\text { Sagging zone } \\
\qquad\left(P_{\mathrm{fl}}\right)_{\mathrm{P}}\end{array}$} & \multicolumn{4}{|c|}{ W-span } & \multicolumn{4}{|c|}{ E-span } & \multirow[t]{3}{*}{$P_{\mathrm{n}}$} & \multicolumn{2}{|c|}{$V_{\mathrm{n}}$} \\
\hline & & \multirow[t]{2}{*}{ W-span } & \multirow[t]{2}{*}{ E-span } & \multicolumn{2}{|c|}{ Interior } & \multicolumn{2}{|c|}{ Exterior } & \multicolumn{2}{|c|}{ Interior } & \multicolumn{2}{|c|}{ Exterior } & & \multirow[t]{2}{*}{ W-span } & \multirow[t]{2}{*}{ E-span } \\
\hline & & & & $\left(P_{\mathrm{cr}}\right)_{\mathrm{I}}$ & $\left(V_{\text {cr }}\right)_{\mathrm{I}}$ & $\left(P_{\mathrm{cr}}\right)_{\mathrm{E}}$ & $\left(V_{\text {cr }}\right)_{\mathrm{E}}$ & $\left(P_{\mathrm{cr}}\right)_{\mathrm{I}}$ & $\left(V_{\text {cr }}\right)_{\mathrm{I}}$ & $\left(P_{\text {cr }}\right)_{\mathrm{E}}$ & $\left(V_{\mathrm{cr}}\right)_{\mathrm{E}}$ & & & \\
\hline L5-40 & 1189 & 670 & 661 & 645 & 183 & - & - & 717 & 197 & - & - & 1529 & 411 & 405 \\
\hline L5-60 & 1055 & 902 & 867 & 852 & 255 & 902 & 180 & 816 & 244 & 937 & 187 & 1635 & 473 & 456 \\
\hline L5-72 & 1600 & 1020 & 1070 & 885 & 285 & 1260 & 265 & 956 & 289 & 1300 & 277 & 1786 & 502 & 492 \\
\hline L10-40 & 415 & 516 & 476 & 300 & 93 & - & - & 226 & 79 & - & - & 717 & 202 & 201 \\
\hline L10-60 & 668 & 754 & 735 & 537 & 173 & - & - & 537 & 171 & - & - & 880 & 264 & 262 \\
\hline L10-72 & 530 & 803 & 836 & 610 & 194 & - & - & 750 & 236 & - & - & 1003 & 302 & 300 \\
\hline H6-40 & 830 & 923 & 1062 & 869 & 270 & 1270 & 240 & 937 & 293 & 1071 & 201 & 2025 & 592 & 590 \\
\hline H6-60 & 1582 & 866 & 854 & 1171 & 345 & 1562 & 321 & 1171 & 343 & 1960 & 407 & 2248 & 633 & 634 \\
\hline H6-72 & 1492 & 1340 & 1340 & 1274 & 411 & - & - & 1416 & 437 & - & - & 2342 & 695 & 698 \\
\hline $\mathrm{H} 10-40$ & 340 & 560 & 500 & 493 & 142 & - & - & 575 & 171 & - & - & 1112 & 335 & 335 \\
\hline $\mathrm{H} 10-60$ & 596 & 793 & 791 & 690 & 228 & 868 & 149 & 690 & 228 & 840 & 143 & 1276 & 373 & 372 \\
\hline $\mathrm{H} 10-72$ & 816 & 803 & 859 & 759 & 252 & - & - & 770 & 255 & - & - & 1282 & 393 & 392 \\
\hline
\end{tabular}




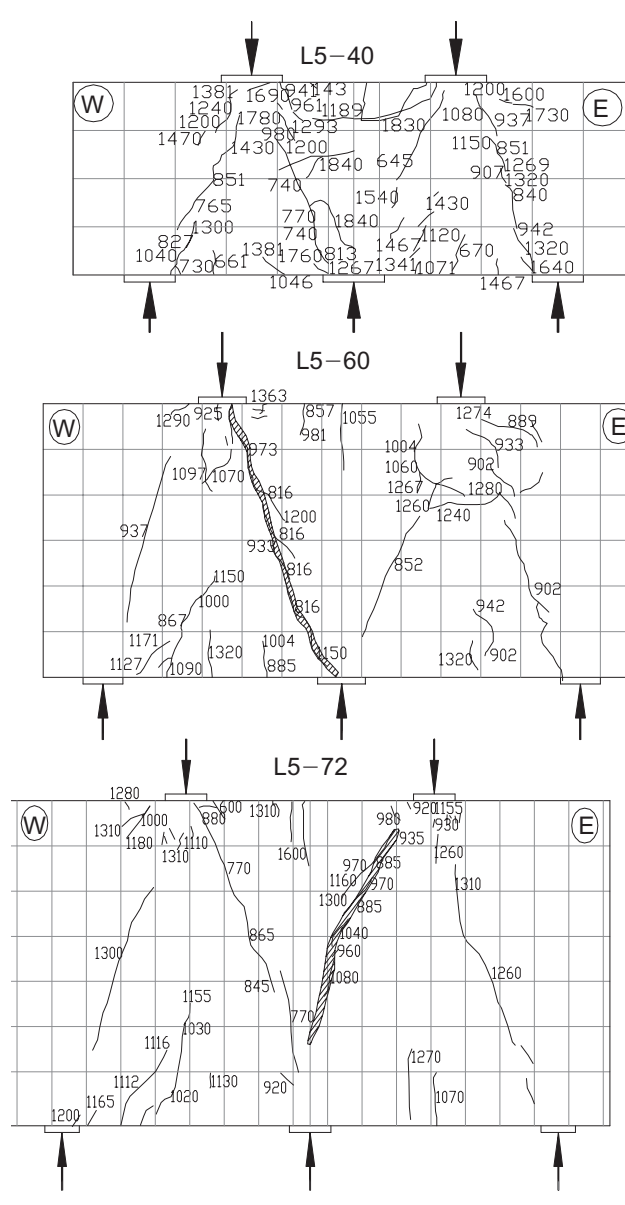

(a)

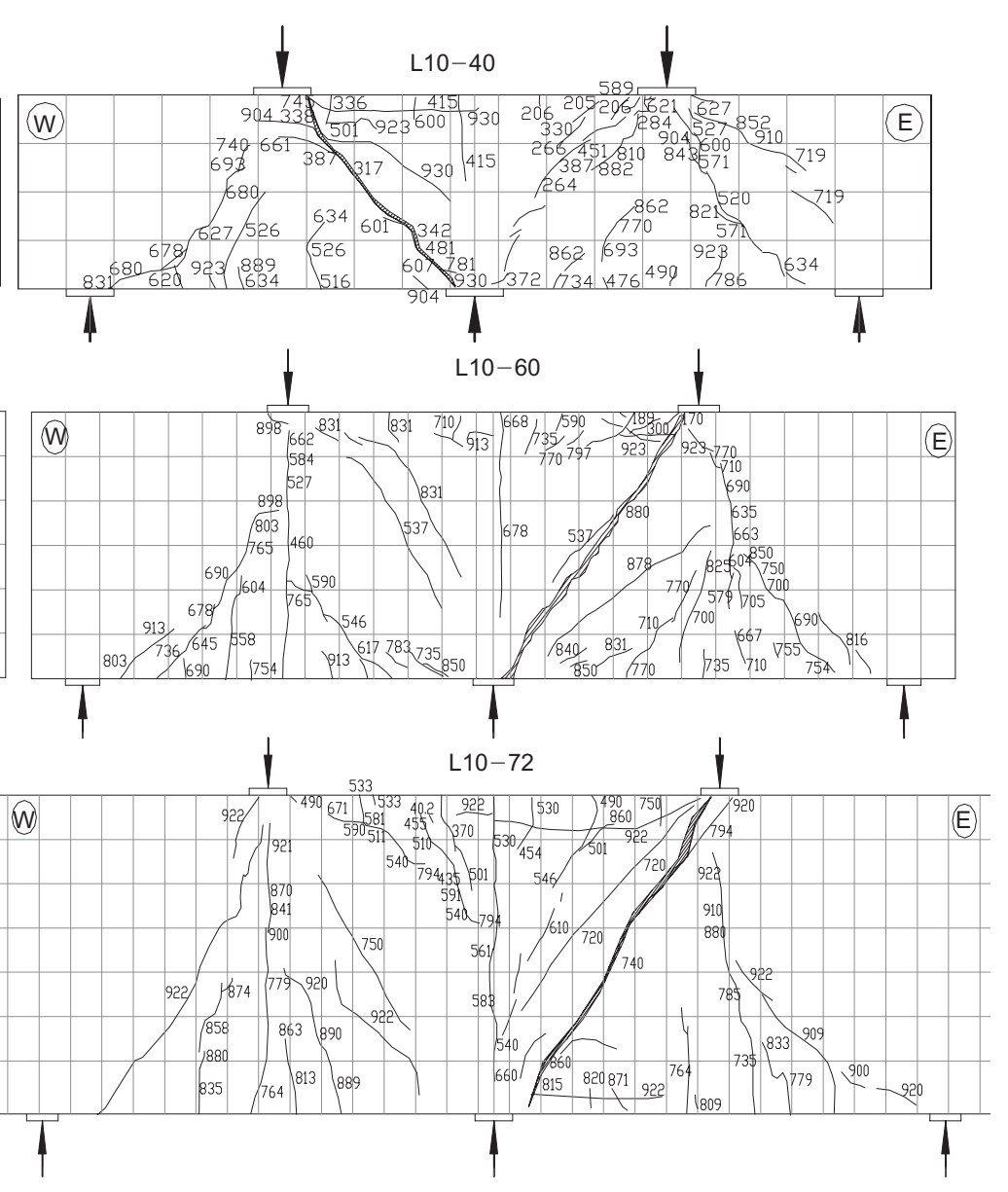

(b)

Fig. 5. Crack patterns and failure mode in L-series beams: (a) a/h=0.5; (b) a/h $=1 \cdot 0$ (numbers indicate the total load in $\mathrm{kN}$ at which crack occurred)

ing the rest of the beam fixed over the other two supports as shown in Fig. 5. The observed failure mode suggests that the mechanism analysis, presented later in the current paper, appears very promising in predicting the load capacity of such beams.

\section{Load-displacement curves}

The mid-span deflections of failed span for different beams tested against the total applied load are given in Fig. 7: Fig. 7(a) for beams in L-series and Fig. 7(b) for beams in H-series. The initial stiffness of beams having the same $a / h$ ratio seems to be independent of the beam overall depth. Also, the development of flexural cracks in sagging and hogging zones had little influence on the stiffness of the beams tested. However, the development of diagonal cracks caused a sharp increase to the beams deflections; the stiffness reduction was especially prominent with the increase of shear span-tooverall depth ratio.

\section{Support reactions}

Figure 8 shows the amount of the load transferred to the exterior and intermediate supports against the total applied load in L-series. On the same figure, the sup- port reactions obtained from a linear 2D FE analysis are also presented. The support reactions obtained from the linear 2D FE analysis are independent of the beam overall depth and shear span-to-overall depth ratio. The distribution of reactions in $\mathrm{H}$-series beams was similar to that of L-series beams; therefore not presented here. Up to the development of the first diagonal crack within the interior shear span, the support reaction against the total applied load in all beams shows good agreement with the results obtained from the linear 2D FE analysis. However, after the first diagonal crack within the interior shear span, the amount of loads transferred to exterior support was a slightly higher than that predicted by the linear 2D FE analysis. The maximum difference between the experimental and the linear 2D FE analytical support reactions increased by up to $10 \%$. This indicates that, although the deep beam has a smaller stiffness after the development of the diagonal crack, the internal redistribution of forces is limited.

\section{Ultimate shear stresses}

The effect of the beam depth, $h$, on the relative ultimate shear stress $\left(v_{\mathrm{n}}\right) /\left(v_{\mathrm{n}}\right)_{h=400 \mathrm{~mm}}$ is given in Fig. 9 . The given relative ultimate shear stress is the normal-

Magazine of Concrete Research, 2007, 59, No. 8 


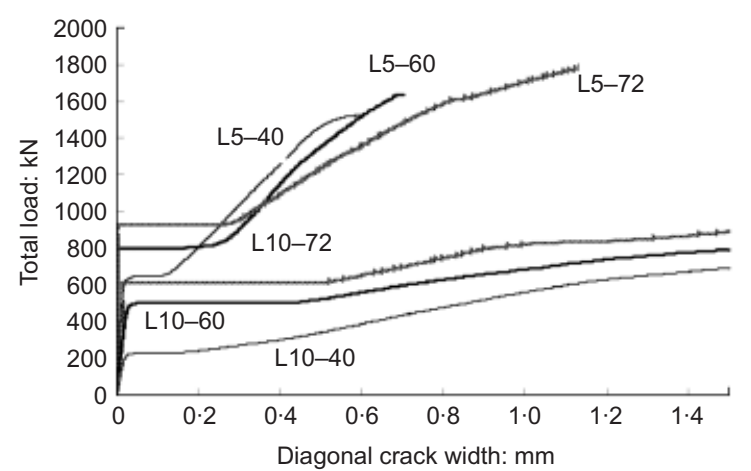

(a)

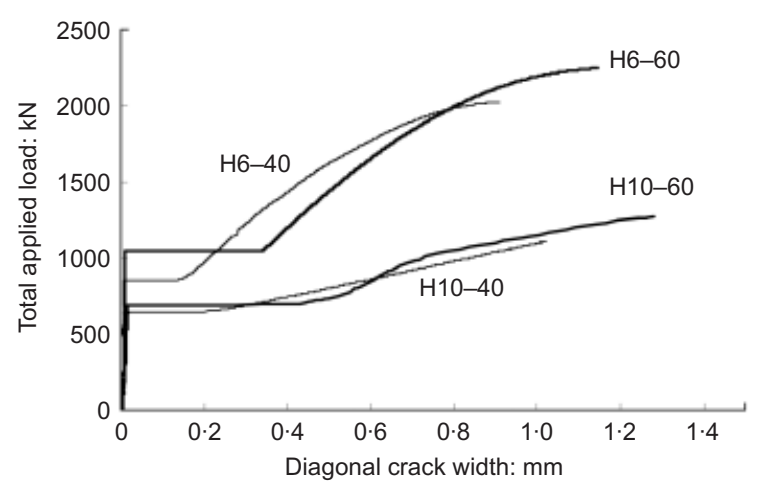

(b)

Fig. 6. Total load plotted against diagonal crack width: (a) L-series beams; (b) H-series beams

ised value, which indicates the ultimate shear stress of each beam, $v_{\mathrm{n}}$, divided by that of the corresponding


simple deep beams shown in Fig. 9 were quoted from the test results of Yang et al., ${ }^{13}$ which had the same material and geometrical properties as the continuous deep beams given in Fig. 1. As section depth increased, the ultimate shear stress gradually decreased. This decreasing rate is higher in $\mathrm{H}$-series beams than in that of L-series beams. The influence of section depth on the structural behaviour of beams was more pronounced in continuous deep beams than in simple ones. This indicates that the flexural cracks in the sagging and hogging regions and the development of tensile strains of the longitudinal top and bottom reinforcement have a greater influence on the reduction of the effective strength of concrete struts within the interior shear span. The test results of simple deep beams performed by Tan and $\mathrm{Lu}^{12}$ and Yang et al. ${ }^{13}$ showed that the ACI $318-99^{5}$ predictions became more unconservative with the increase of section depth. As size effect of continuous reinforced concrete deep beams is more notable, it can be concluded that the shear provision of the ACI 318-99 is also inadequate in the case of continuous deep beams.

\section{Strain distribution of longitudinal reinforcement}

Figures 10 and 11 show the variation of strains in the longitudinal top and bottom reinforcement of the beams

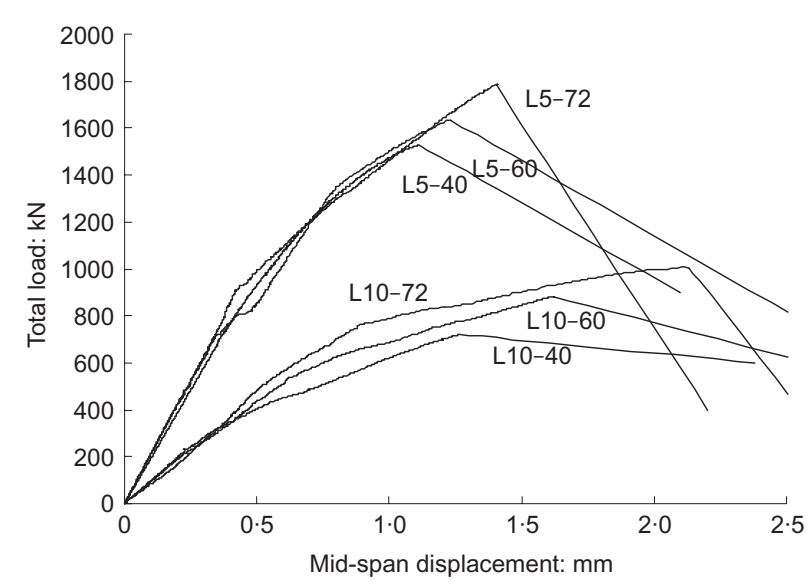

(a)

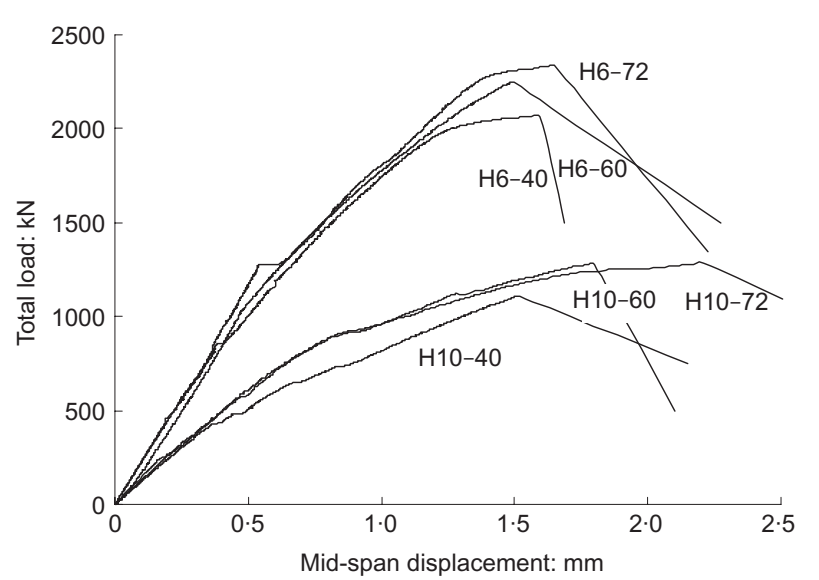

(b)

Fig. 7. Total load plotted against mid-span displacement: (a) L-series beams; (b) H-series beams

tested against the total applied load, respectively. However, strains in the longitudinal top and bottom reinforcement were recorded at $50 \mathrm{~mm}$ and $100 \mathrm{~mm}$ spacing for beams having $a / h=0.5$ and $1 \cdot 0$, respectively; only strains at the regions crossing the diagonal crack developed between the edges of the load and intermediate support plates are presented as those were the highest strains measured. Although both top reinforcement in the sagging region and bottom reinforcement in the hogging region experienced compressive strains until before the first diagonal cracking load, their strains moved dramatically to tensile strains with the occurrence of diagonal cracks. The tensile strain of longitudinal reinforcement developed owing to the tie action increased slightly with the increase of $h$, but at no stage did it reach the yield strain given in Fig. 2.

\section{Upper-bound analysis for ultimate strength}

As proposed by Ashour and Morley, ${ }^{16}$ the mechanism of failure for two-span deep beams can be classified into two different modes: unsymmetrical collapse where the diagonal failure plane occurs within only one of the two interior shear spans and symmetrical collapse within the two interior shear spans. All beams tested in this study were collapsed owing to the non- 


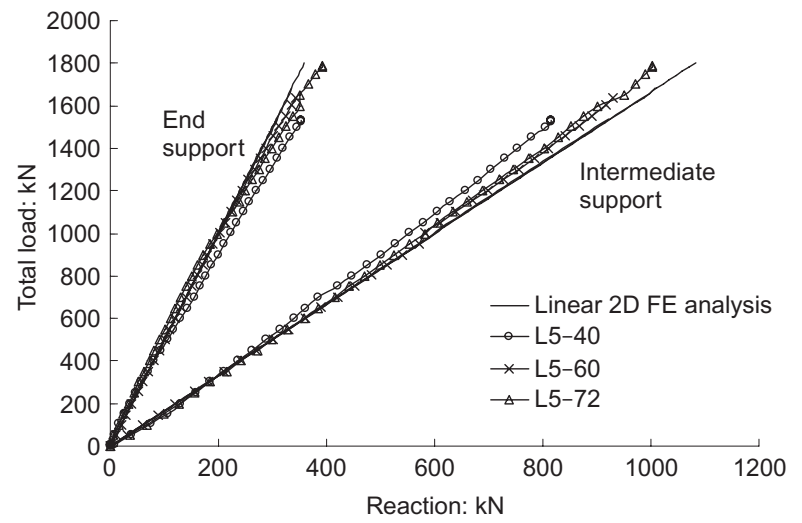

(a)

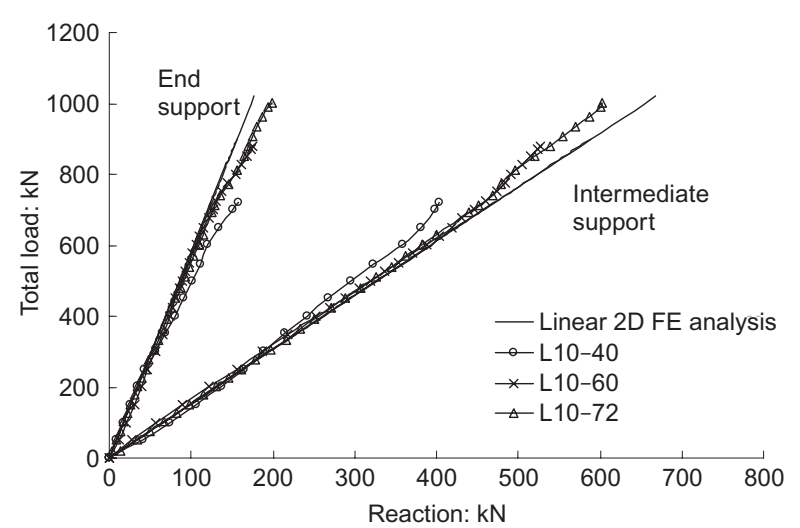

(b)

Fig. 8. Support reactions against total load in L-series beams: (a) beams having $a / h=0 \cdot 5$; (b) beams having a/ $h=1 \cdot 0$

symmetrical failure mode as shown in Fig. 5 as test specimens had no shear reinforcement that would promote internal stress redistribution after the development of diagonal cracks.

Figure 12 shows the idealised unsymmetrical failure mode based on test results of the two-span continuous deep beams. As proposed by Ashour and Morley ${ }^{17}$ and Wang et al., ${ }^{18}$ a yield line can generally be represented as a parabolic line connecting the edges of the load and intermediate support plates. As a result, continuous deep beams, at collapse, usually can be idealised as an assemblage of two rigid blocks separated by a yield line. The rigid block II is fixed over both the intermediate and exterior supports and the other rigid block, rigid block I, rotates about an instantaneous centre (IC).

\section{Modelling of materials}

Concrete is modelled as a rigid perfectly plastic material obeying the modified Coulomb failure criteria with zero tension cut-off. ${ }^{19}$ The effective compressive strength, $f_{\mathrm{c}}^{*}$, to be used in calculation, is obtained from the cylinder compressive strength, $f_{\mathrm{c}}^{\prime}$, as follows

$$
f_{\mathrm{c}}^{*}=v_{\mathrm{e}} f_{\mathrm{c}}^{\prime}
$$

where $v_{\mathrm{e}}$ is the effectiveness factor that is introduced to account for the limited ductility of concrete and to

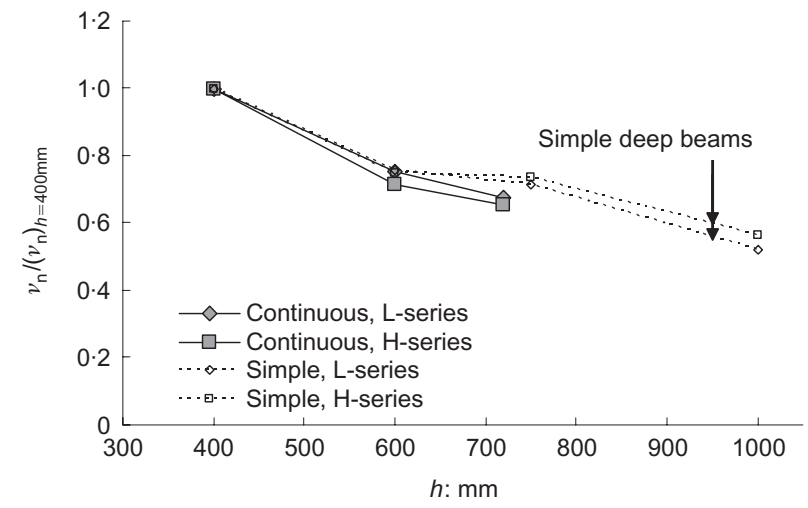

(a)

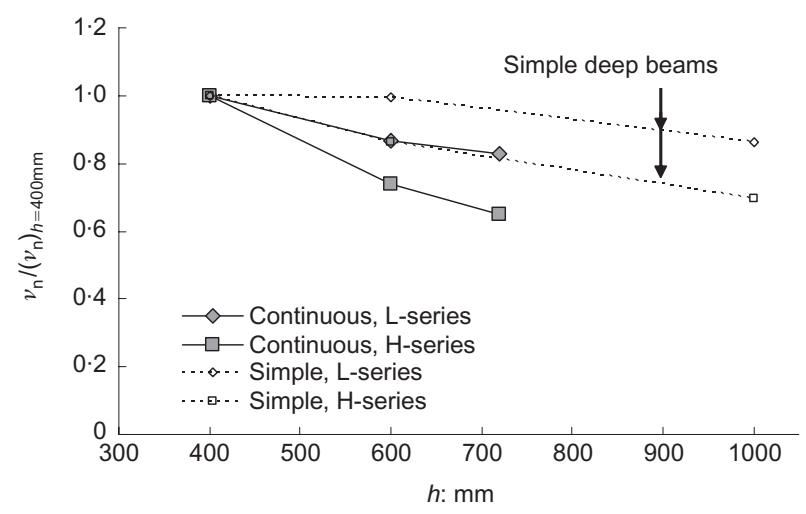

(b)

Fig. 9. Normalised ultimate shear stress plotted against overall depth of beams tested: (a) beams having al $h=0 \cdot 5(0 \cdot 6)$; (b) beams having $a / h=1 \cdot 0$

absorb other shortcomings of applying the theory of plasticity to concrete. The effectiveness factor normally depends on material strength and geometrical properties of reinforced concrete members such as size, shear span-to-depth ratio, amount and configuration of reinforcement, and loading system. ${ }^{16,18,20}$

Tensile and compressive reinforcement are generally assumed as a rigid perfectly plastic material with yield stress $f_{\mathrm{y}}$. However, high-strength reinforcement having yield stress above $500 \mathrm{MPa}$ may not reach its yield strength if the amount of reinforcement is heavy and bearing or local compressive failure in concrete strut is preceded. In fact, the shear provision of ACI 318-05 ${ }^{14}$ has recommended that the value of $f_{\mathrm{y}}$ used in design of shear reinforcement should not exceed $420 \mathrm{MPa}$ to provide ductility and control on diagonal crack width. In addition, stresses in all longitudinal reinforcing bars at ultimate strength of tested beams were below $400 \mathrm{MPa}$ as the highest strain recorded was 0.002 as shown in Figs 10 and 11. In the current study, therefore, the value of $f_{\mathrm{y}}$ of reinforcement is limited to $420 \mathrm{MPa}$.

\section{Work equation}

The upper-bound theorem is based on the energy principle equating the total internal energy, $W_{\mathrm{I}}$, to the

Magazine of Concrete Research, 2007, 59, No. 8 




(a)

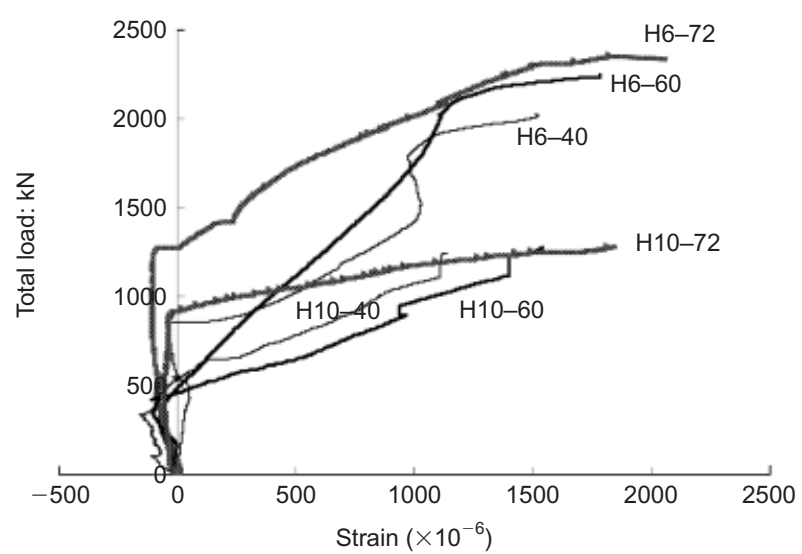

(b)

Fig. 10. Total load-strain relation of longitudinal top reinforcement at load point: (a) L-series beams; (b) H-series beams

external work, $W_{\mathrm{E}}$. The total internal energy mainly depends on the position of the instantaneous centre and the amount of internal stresses in both concrete along the hyperbolic yield line and reinforcement crossing the yield line. Because the relative displacement rate, $\delta$, equals $\omega r$ as shown in Fig. 12, the energy, $W_{\mathrm{c}}$, dissipated in concrete in the hyperbolic yield line proposed by Nielsen ${ }^{19}$ is

$$
W_{\mathrm{c}}=\frac{b_{\mathrm{w}} f_{\mathrm{c}}^{*}}{2} \omega r(1-\sin \alpha) \frac{h}{\sin \beta}
$$

where $r$ is the distance between the midpoint of the chord of the yield line and the instantaneous centre; $\omega$ is the rotational displacement of rigid block I; $\alpha$ is the angle between the relative displacement at the midpoint of the chord and yield line chord; and $\beta$ is the angle between the yield line and longitudinal axis as shown in Fig. 12. The relative displacement of reinforcement, $\delta_{\mathrm{s}}$, can be expressed as $\omega r_{\mathrm{s}}$ as shown in Fig. 13. Therefore the energy, $W_{\mathrm{s}}$, dissipated in reinforcement crossing the yield line is calculated from

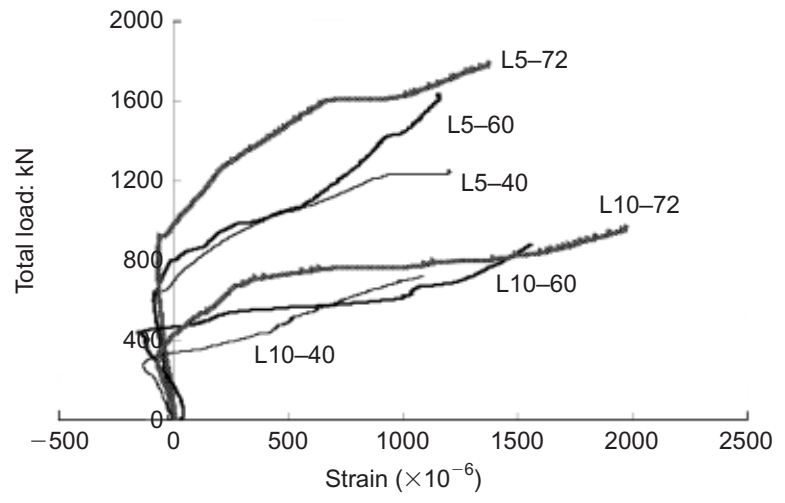

(a)

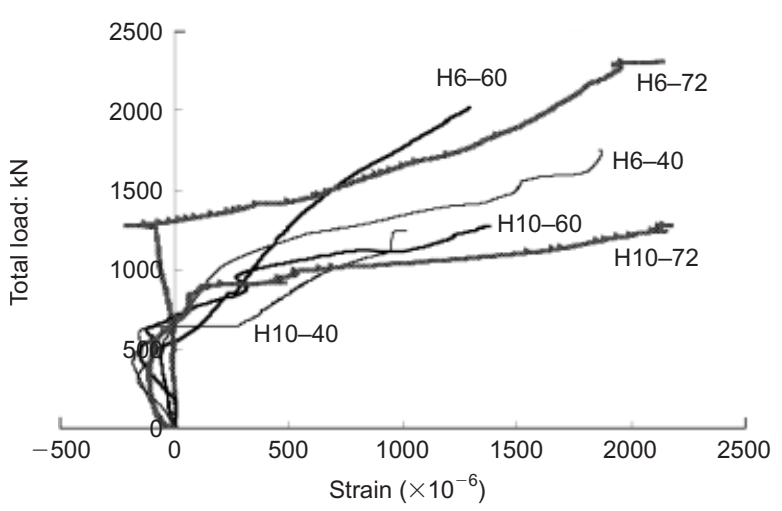

(b)

Fig. 11. Total load-strain relation of longitudinal bottom reinforcement at intermediate support: (a) L-series beams; (b) $H$-series beams

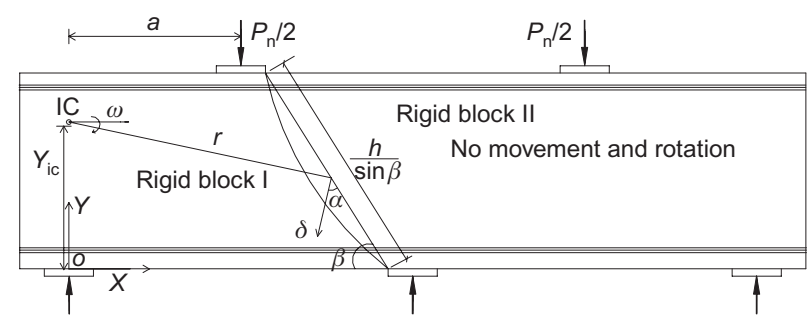

Fig. 12. Idealised failure mechanism in two-span continuous deep beams

$$
W_{\mathrm{s}}=\sum_{i=1}^{n} \omega\left(A_{\mathrm{s}}\right)_{i}\left(f_{\mathrm{y}}\right)_{i}\left(r_{\mathrm{s}}\right)_{i} \cos \left(\alpha_{\mathrm{s}}\right)_{i}
$$

where $n$ is the number of reinforcing bars crossing the yield line; $\left(A_{\mathrm{s}}\right)_{i}$, and $\left(f_{\mathrm{y}}\right)_{i}$ is the area and yield strength of the reinforcing bar $i$ crossing the yield line, respectively; $\left(r_{\mathrm{s}}\right)_{i}$ is the distance between the reinforcing bar $i$ and the instantaneous centre; and $\left(\alpha_{\mathrm{s}}\right)_{i}$ is the angle between the relative displacement $\delta_{\mathrm{s}}$ about IC and the reinforcing bar $i$ crossing the yield line. In Fig. 13 the angle, $\alpha_{\mathrm{s}}$, between reinforcement and beam longitudinal axis is 0 and $\pi / 2$ for horizontal and vertical reinforcement, respectively. Therefore $\cos \left(\alpha_{\mathrm{s}}\right)_{i}$ in equation (3) 


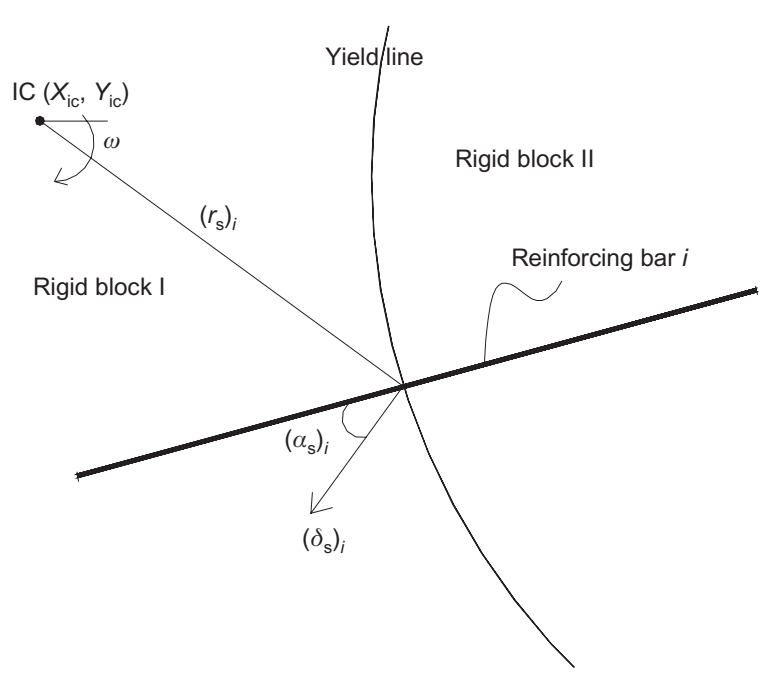

Fig. 13. Reinforcement crossing yield line

can be easily calculated for horizontal and vertical reinforcement as follow

$$
\begin{aligned}
\cos \left(\alpha_{\mathrm{s}}\right)_{i}= & \left|Y_{\mathrm{ic}}-y_{i}\right| /\left(r_{\mathrm{s}}\right)_{i} \\
& \text { for horizontal reinforcement } \\
= & \left|X_{\mathrm{ic}}-x_{i}\right| /\left(r_{\mathrm{s}}\right)_{i} \text { for vertical reinforcement }
\end{aligned}
$$

where $y_{i}$, and $x_{i}$ are the vertical and the horizontal distance between the origin of global coordinates and reinforcement $i$ crossing the yield line, respectively. The external work, $W_{\mathrm{E}}$, done by the vertical load $P_{\mathrm{n}} / 2$ on rigid block $\mathrm{I}$ in Fig. 12 is

$$
W_{\mathrm{E}}=\frac{P_{\mathrm{n}}}{2} \omega a
$$

where $a$ is the shear span which is the distance between the load point and centre of exterior support. Equating the total internal energy dissipated in concrete and reinforcement to the external work done, the ultimate strength, $P_{\mathrm{n}}$, can be written in the following form

$$
\begin{aligned}
P_{\mathrm{n}}= & \frac{b_{\mathrm{w}} h}{a}\left[f_{\mathrm{c}}^{*} r(1-\sin \alpha) \frac{1}{\sin \beta}\right. \\
& \left.+2 \sum_{i=1}^{n}\left(\rho_{\mathrm{s}}\right)_{i}\left(f_{\mathrm{y}}\right)_{i}\left(r_{\mathrm{s}}\right)_{i} \cos \left(\alpha_{\mathrm{s}}\right)_{i}\right]
\end{aligned}
$$

where $\left(\rho_{\mathrm{s}}\right)_{i}$ is the the reinforcement ratio $i$ crossing the yield line, which can be calculated from $\left(A_{\mathrm{s}}\right)_{i} / b_{\mathrm{w}} h$.

\section{Effectiveness factor of concrete}

The web of deep beams is considered to be in a state of biaxial tension-compression. The presence of simultaneous transverse tensile strain leads to a significant deterioration of the compressive strength of cracked concrete. ${ }^{21}$ This means that the softening behaviour of cracked concrete depends on the material properties and the amount of transverse tensile strain in the yield line. The softening behaviour has been investigated and reviewed in panel tests subjected to biaxial tensioncompression by several researchers. ${ }^{21-24}$ In particular, Vecchio and Collins ${ }^{21}$ proposed the effectiveness factor as a function of the concrete strength and the ratio of the principal strains based on a large number of experimental data. In the present study, Vecchio and Collins' model for effectiveness factor was adopted and modified to reflect the influence of size effect as follows

$$
\begin{aligned}
v_{\mathrm{e}} & =\frac{\xi}{1 \cdot 0+K_{\mathrm{c}} K_{\mathrm{f}}} \\
K_{\mathrm{c}} & =0 \cdot 35\left(-\frac{\varepsilon_{1}}{\varepsilon_{3}}-0 \cdot 28\right)^{0 \cdot 8} \geqslant 1 \cdot 0 \\
K_{\mathrm{f}} & =0 \cdot 1825 \sqrt{f_{\mathrm{c}}^{\prime}} \geqslant 1 \cdot 0 \\
\xi & =\frac{1}{\sqrt{1+\left(d / 25 d_{\mathrm{a}}\right)}}
\end{aligned}
$$

where $\varepsilon_{1}$ and $\varepsilon_{3}$ are the principal tensile and compressive strains in the yield line, respectively. As the principal strains $\varepsilon_{1,3}$ are $(1 / 2)(\delta / \Delta)(\sin \alpha \pm 1)$ in the yield line having discontinuous width of $\Delta$ from the plasticity theory, ${ }^{17,19}-\varepsilon_{1} / \varepsilon_{3}$ in the factor $K_{\mathrm{c}}$ can be written as $1+\sin \alpha / 1-\sin \alpha$. This indicates that the influence of the transverse tensile strain on the effectiveness factor can be determined by the angle $\alpha$. The factor $\xi$ proposed by Bažant and Kim, ${ }^{8}$ which is a function of the effective depth, $d$, and maximum size of aggregate, $d_{\mathrm{a}}$, using non-linear fracture mechanics and a non-linear regression analysis based on hundreds of test data, is to consider the influence of the size effect which is more significant in continuous deep beams. The size effect in reinforced concrete beams should be hardly influenced by the shear span-to-depth ratio as discovered by Bažant and $\mathrm{Kim}^{8}{ }^{8}$ Although the factor $\xi$ is based on test results of slender beams, its validity is extended here to deep beams.

\section{Solution procedure}

The ultimate strength is implicitly expressed as a function of the position of the instantaneous centre $\left(X_{\mathrm{ic}}, Y_{\mathrm{ic}}\right)$ as given in equation (6). The horizontal coordinate $\left(X_{\text {ic }}\right)$ of the instantaneous centre coincides with that of the global coordinates since the vertical displacement of rigid block I is prevented at the exterior support as shown in Fig. 12. According to the upper-bound theorem, the collapse occurs at the least strength. The minimum value of strength is obtained by varying the vertical coordinate $\left(Y_{\text {ic }}\right)$ of the instantaneous centre along the vertical axis of the global coordinate. The process of adjusting the vertical coordinate $\left(Y_{\text {ic }}\right)$, which was programmed using Matlab software, is achieved by reliable numerical optimisation procedures.

Magazine of Concrete Research, 2007, 59, No. 8 


\section{Comparison of predicted and experimental failure} loads

Table 3 and Fig. 14 show comparisons between theoretical and experimental failure loads of continuous deep beams. The test results of continuous deep beams tested by Ashour, ${ }^{1}$ Rogowsky et al. $^{3}$ and Subedi, ${ }^{4}$ which failed in unsymmetrical failure mechanism shown in Fig. 12, are also presented in Table 3 and Fig. 14. The mean and standard deviation of the ratio between the proposed and experimental ultimate strengths $\left(P_{\mathrm{n}}\right)_{\text {Pro. }} /\left(P_{\mathrm{n}}\right)_{\text {Exp. }}$ are 0.973 and 0.093 , respectively. The predictions obtained from equation (6) show good agreement with experimental results and the ratio $\left(P_{\mathrm{n}}\right)_{\text {Pro. }} /\left(P_{\mathrm{n}}\right)_{\text {Exp. }}$ remains constant, even though section depth of beams is varied. This indicates that the size effect is successfully represented by the effectiveness factor given in equation (7).

Test results presented in Table 3 showed that the normalised load capacity, $\lambda_{\mathrm{n}}=P_{\mathrm{n}} / 2 b_{\mathrm{w}} h f_{\mathrm{c}}^{\prime}$, of beams tested by Ashour ${ }^{1}$ and Rogowsky et al. ${ }^{3}$ decreased with

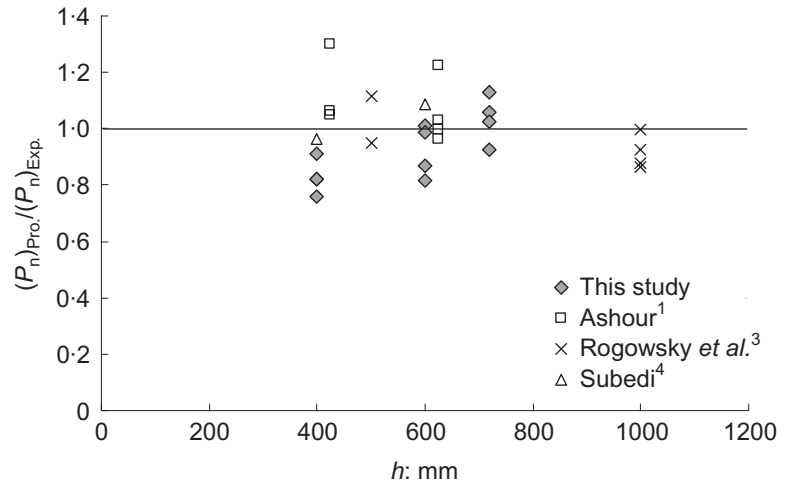

Fig. 14. Comparison between theoretical and experimental ultimate capacity for continuous deep beams according to section depth

the increase in the shear span-to-overall depth ratio as observed in the present investigation. However, the presence of shear reinforcement in beams tested by other researchers enhanced their normalised load capacity. In addition, for the range of shear span-to-overall depth

Table 3. Basic data and comparison between experimental and theoretical ultimate strengths

\begin{tabular}{|c|c|c|c|c|c|c|c|c|c|c|c|c|c|}
\hline \multirow[t]{2}{*}{ Researcher } & \multirow[t]{2}{*}{ Specimen } & \multirow[t]{2}{*}{$f_{\mathrm{c}}^{\prime}: \mathrm{MPa}$} & \multirow[t]{2}{*}{$h: \mathrm{mm}$} & \multirow[t]{2}{*}{$a / h$} & \multicolumn{2}{|c|}{$\begin{array}{l}\text { Longitudinal } \\
\text { reinforcements*: } \\
\mathrm{mm}^{2}\end{array}$} & \multicolumn{2}{|c|}{ Shear reinforcements $\dagger$} & \multicolumn{2}{|c|}{$P_{\mathrm{n}}: \mathrm{kN}$} & \multicolumn{2}{|c|}{$\lambda_{\mathrm{n}}=\frac{P_{\mathrm{n}}}{2 b_{\mathrm{w}} h f_{\mathrm{c}}^{\prime}}$} & \multirow[t]{2}{*}{$\frac{\left(P_{\mathrm{n}}\right)_{\text {Pro. }}}{\left(P_{\mathrm{n}}\right)_{\text {Exp. }}}$} \\
\hline & & & & & Bottom & Top & Vertical & Horizontal & Exp. & Pro. & Exp. & Pro. & \\
\hline \multirow[t]{12}{*}{ Present study } & L5-40 & $32 \cdot 4$ & 400 & $0 \cdot 5$ & 574 & 574 & - & - & 1529 & 1252 & $0 \cdot 369$ & $0 \cdot 302$ & $0 \cdot 819$ \\
\hline & L5-60 & $32 \cdot 4$ & 600 & $0 \cdot 5$ & 861 & 861 & & & 1635 & 1652 & $0 \cdot 263$ & $0 \cdot 266$ & $1 \cdot 010$ \\
\hline & L5-72 & $32 \cdot 4$ & 720 & $0 \cdot 5$ & 1148 & 1148 & & & 1786 & 2016 & 0.239 & $0 \cdot 270$ & $1 \cdot 129$ \\
\hline & L10-40 & $32 \cdot 1$ & 400 & $1 \cdot 0$ & 574 & 574 & & & 717 & 652 & $0 \cdot 175$ & $0 \cdot 159$ & 0.909 \\
\hline & L10-60 & $32 \cdot 1$ & 600 & $1 \cdot 0$ & 861 & 861 & & & 880 & 868 & $0 \cdot 143$ & $0 \cdot 141$ & $0 \cdot 986$ \\
\hline & L10-72 & $32 \cdot 1$ & 720 & $1 \cdot 0$ & 1148 & 1148 & & & 1003 & 1060 & $0 \cdot 136$ & $0 \cdot 143$ & $1 \cdot 057$ \\
\hline & H6-40 & $65 \cdot 1$ & 400 & $0 \cdot 6$ & 574 & 574 & & & 2025 & 1538 & $0 \cdot 243$ & $0 \cdot 185$ & $0 \cdot 760$ \\
\hline & H6-60 & $65 \cdot 1$ & 600 & $0 \cdot 6$ & 861 & 861 & & & 2248 & 1830 & $0 \cdot 180$ & $0 \cdot 146$ & $0 \cdot 814$ \\
\hline & H6-72 & $65 \cdot 1$ & 720 & $0 \cdot 6$ & 1148 & 1148 & & & 2342 & 2168 & $0 \cdot 156$ & $0 \cdot 145$ & 0.926 \\
\hline & $\mathrm{H} 10-40$ & $67 \cdot 5$ & 400 & $1 \cdot 0$ & 574 & 574 & & & 1112 & 914 & $0 \cdot 129$ & $0 \cdot 106$ & $0 \cdot 822$ \\
\hline & H10-60 & $68 \cdot 2$ & 600 & $1 \cdot 0$ & 861 & 861 & & & 1276 & 1106 & 0.098 & 0.085 & $0 \cdot 867$ \\
\hline & H10-72 & $67 \cdot 5$ & 720 & $1 \cdot 0$ & 1148 & 1148 & & & 1282 & 1314 & 0.082 & $0 \cdot 084$ & $1 \cdot 025$ \\
\hline \multirow[t]{7}{*}{ Ashour $^{1}$} & CDB1 & 30 & 625 & 1.08 & 452 & 609 & 5-Ф8 & 8- $\Phi 8$ & 1078 & 1320 & $0 \cdot 240$ & $0 \cdot 293$ & $1 \cdot 224$ \\
\hline & CDB2 & $33 \cdot 1$ & 625 & $1 \cdot 08$ & 452 & 609 & 2-Ф8 & 4-Ф8 & 931 & 958 & $0 \cdot 188$ & $0 \cdot 193$ & 1.029 \\
\hline & CDB4 & 28 & 625 & $1 \cdot 08$ & 452 & 609 & 2-Ф8 & - & 867 & 864 & $0 \cdot 207$ & $0 \cdot 206$ & 0.996 \\
\hline & CDB5 & $28 \cdot 7$ & 625 & $1 \cdot 08$ & 226 & 226 & 2-Ф8 & 4-Ф8 & 803 & 774 & $0 \cdot 187$ & $0 \cdot 180$ & 0.963 \\
\hline & CDB6 & $22 \cdot 5$ & 425 & 1.6 & 383 & 383 & 2-Ф6 & 4-Ф6 & 485 & 630 & $0 \cdot 211$ & $0 \cdot 275$ & $1 \cdot 299$ \\
\hline & CDB7 & $26 \cdot 7$ & 425 & $1 \cdot 6$ & 383 & 383 & $5-\Phi 6$ & $2-\Phi 6$ & 436 & 464 & $0 \cdot 160$ & $0 \cdot 170$ & $1 \cdot 064$ \\
\hline & CDB8 & $23 \cdot 6$ & 425 & $1 \cdot 6$ & 157 & 157 & 2-Ф6 & 2-Ф6 & 377 & 396 & $0 \cdot 157$ & $0 \cdot 165$ & $1 \cdot 050$ \\
\hline \multirow{6}{*}{$\begin{array}{l}\text { Rogowsky } \\
\text { et al. }{ }^{3}\end{array}$} & BM 3/1 & $28 \cdot 9$ & 1000 & $1 \cdot 1$ & 895 & 1193 & 4-Ф6 & - & 2167 & 1902 & $0 \cdot 187$ & $0 \cdot 165$ & $0 \cdot 878$ \\
\hline & BM 3/2 & $42 \cdot 5$ & 500 & $2 \cdot 2$ & 960 & 960 & 4-Ф6 & - & 847 & 944 & $0 \cdot 100$ & $0 \cdot 111$ & $1 \cdot 115$ \\
\hline & $\mathrm{BM} 4 / 2$ & $38 \cdot 3$ & 500 & $2 \cdot 2$ & 960 & 960 & - & 4-Ф6 & 597 & 566 & 0.078 & $0 \cdot 074$ & 0.948 \\
\hline & BM 5/1 & $36 \cdot 9$ & 1000 & $1 \cdot 1$ & 895 & 1193 & $16-\Phi 6$ & - & 2559 & 2556 & $0 \cdot 173$ & $0 \cdot 173$ & 0.999 \\
\hline & BM 6/1 & $35 \cdot 8$ & 1000 & $1 \cdot 1$ & 895 & 1193 & - & $12-\Phi 6$ & 2190 & 1896 & $0 \cdot 153$ & $0 \cdot 132$ & $0 \cdot 866$ \\
\hline & BM 7/1 & $34 \cdot 5$ & 1000 & $1 \cdot 1$ & 895 & 1193 & - & - & 1409 & 1304 & $0 \cdot 102$ & 0.094 & 0.925 \\
\hline \multirow[t]{2}{*}{ Subedi ${ }^{4}$} & $1 \mathrm{CB} 2$ & $56 \cdot 5$ & 400 & $1 \cdot 25$ & 201 & 201 & 2-Ф6 & 2-Ф6 & 360 & 346 & $0 \cdot 159$ & $0 \cdot 153$ & 0.961 \\
\hline & $2 \mathrm{CB} 4$ & $44 \cdot 7$ & 600 & $1 \cdot 4$ & 628 & 226 & 7-Ф6 & 5-Ф6 & 840 & 914 & $0 \cdot 209$ & $0 \cdot 227$ & $1 \cdot 088$ \\
\hline Mean & & & & & & & & & & & & & $0 \cdot 982$ \\
\hline Std & & & & & & & & & & & & & $0 \cdot 126$ \\
\hline
\end{tabular}

* The limiting value of the yield strength of reinforcement $=420 \mathrm{MPa}$

$\uparrow$ Total number of shear reinforcements crossing the yield line 
ratios investigated, the vertical shear reinforcement had a slightly higher effect on the normalised load capacity (for example, compare beams BM 3/2 and BM 4/2).

\section{Conclusions}

The following conclusions may be drawn from the work presented above.

(a) The failure plane of two-span continuous deep beams without shear reinforcement was formed unsymmetrically, within one interior shear span only, along a diagonal crack connecting the edges of the load and intermediate support plates.

(b) As the load increased, widening of the diagonal crack greatly increased with the increase of shear span-to-overall depth ratio. All beams having $a / h$ $=1.0$ failed soon after the development of the diagonal crack. Whereas for beams having $a / h=$ $0 \cdot 5$, the development rate of the diagonal crack width increased with the increase of section overall depth.

(c) The influence of section depth on shear behaviour of beams was more pronounced on continuous deep beams than simple ones. Also, the size effect was more prominent in beams having concrete strength of $65 \mathrm{MPa}$ than those having concrete strength of $32 \mathrm{MPa}$.

(d) The highest tensile strain recorded in longitudinal top and bottom reinforcement in each beam was at the region crossing diagonal cracks, and it slightly increased with the increase of section depth but did not reach the yield strain.

(e) The proposed formulae to predict the ultimate strength of two-span continuous deep beams were in reasonable agreement with experiments, even though the section depth of beams was varied.

\section{Acknowledgement}

This work was supported by the Korea Research Foundation Grant (KRF-2003-041-D00586) and the Regional Research Centers Program (Bio-housing Research Institute), granted by the Korean Ministry of Education \& Human Resources Development.

\section{References}

1. Ashour A. F. Tests of reinforced concrete continuous deep beams. ACI Structural Journal, 1997, 94, No. 1, 3-12.

2. Chemrouk M. and Kong F. K. High strength concrete continuous deep beams-with web reinforcement and shear-span variations. Advances in Structural Engineering, 2004, 7, No. 3, 229-243.

3. Rogowsky D. M., MacGregor J. G. and Ong S. Y. Tests of reinforced concrete deep beams. ACI Journal, 1986, 83, No. 4, 614-623.

4. Subedi N. K. Reinforced concrete two-span continuous deep beams. Proceedings of the Institution of Civil Engineers, Structures and Buildings, 1998, 128, No. 1, 12-25.

5. American Concrete Institute. Building Code Requirements for Structural Concrete (318-99) and Commentary (318R-99). ACI, Detroit, 1999. ACI Committee 318.

6. Construction Industry Research and Information AssoCIATION. CIRIA Guide 2. The Design of Deep Beams in Reinforced Concrete. Ove Arup and Partners. CIRIA, London, 1984.

7. BaŽant Z. P. and Planas J. Fracture and Size Effect in Concrete and Other Quasibrittle Materials. CRC Press, Boca Raton, Florida, 1998.

8. BAŽAnT Z. P. and KIM J. K. Size effect in shear failure of longitudinally reinforced beams. ACI Journal, 1984, 81, No. 5, 456-468.

9. REgan P. E. Research on shear: a benefit to humanity or a waste of time? The Structural Engineer, 1993, 71, No. 19, 337347.

10. TAYLOR H. P. J. Shear strength of large beams. Journal of Structural Engineering, ASCE, 1972, 96, No. ST11, 2473-2490.

11. Walraven J. and Lehwalter N. Size effects in short beams loaded in shear. ACI Structural Journal, 1994, 91, No. 5, 585593.

12. TAN K. H. and LU H. Y. Shear behavior of large reinforced concrete deep beams and code comparisons. ACI Structural Journal, 1999, 96, No. 5, 836-845.

13. Yang K. H., Eun H. C, Chung H. S. and Lee E. T. Shear characteristics of high-strength concrete deep beams without shear reinforcement. Engineering Structures, 2003, 25, No. 8, 1343-1352.

14. American Concrete Institute. Building Code Requirements for Structural Concrete and Commentary (318R-05). ACI, Detroit, 2005. ACI Committee 318.

15. REINECK K. H. Model for structural concrete members without transverse reinforcement. Proceedings of IABSE Colloquium on Structural Concrete, Stuttgart, 1991, Vol. 62, pp. 643-648.

16. Ashour A. F. and Morley C. T. Effectiveness factor of concrete in continuous deep beams. Journal of Structural Engineering, ASCE, 1996, 122, No. 2, 169-178.

17. Ashour A. F. and Morley C. T. The numerical determination of shear failure mechanisms in reinforced concrete beams. The Structural Engineer, 1994, 72, No. 23 and 24, 395-400.

18. Wang W., Jiang D. H. and Hsu C. T. T. Shear strength of reinforced concrete deep beams. Journal of Structural Engineering, ASCE, 1993, 119, No. 8, 2294-2312.

19. Nielsen M. P. Limit Analysis and Concrete Plasticity. PrenticeHall, Englewood Cliffs, 1984.

20. Zhang J. P. Diagonal cracking and shear strength of reinforced concrete beams. Magazine of Concrete Research, 1997, 49, No. $178,55-65$.

21. Vecchio F. J. and Collins M. P. Compression response of cracked reinforced concrete. Journal of Structural Engineering, ASCE, 1993, 119, No. 12, 3590-3610.

22. Belarbi A. and Hsu T. C. Softened concrete in biaxial tension-compression. ACI Structural Journal, 1995, 92, No. 5, $562-573$.

23. Duthinh D. Sensitivity of shear strength of reinforced concrete and prestressed concrete beams to shear friction and concrete softening according to modified compression field theory. ACI Structural Journal, 1999, 96, No. 4, 495-508.

24. TANABE T. and WU Z. Strain softening under biaxial tension and compression. IABSE Colloquium on Structural Concrete, Stuttgart, 1991, 62, 623-636.

Discussion contributions on this paper should reach the editor by 1 April 2008 